\title{
Assessment of safe injection practices in health facilities in Oman
}

Salah Al Awaidy, ${ }^{1}$ Bassem Zayed, ${ }^{2}$ Moustapha Ramadan ${ }^{3}$ and Mohamed Hsairi ${ }^{4}$

${ }^{1}$ Health Affairs Office; ${ }^{2}$ Infection Control Programme, Ministry of Health, Muscat, Oman (Correspondence to: Salah T. Al Awaidy: salah.awaidy@gmail. com). ${ }^{3}$ Department of Hospital Epidemiology and Infection Control, Alexandria University Hospitals, Alexandria, Egypt. ${ }^{4}$ Department of Public Health, National Institute of Public Health, Ministry of Health, Tunis, Tunisia.

\begin{abstract}
Background: Unsafe injection practices put patients and providers at risk of infectious and noninfectious adverse events. A 2001 Ministry of Health survey on injection practices in Oman indicated that, while overall standards were good, in some areas there was a need for improvement.
\end{abstract}

Aim: We aimed to evaluate injection safety practices to determine whether facilities meet the requirements for practices, equipment, supplies and waste disposal, and to identify unsafe practices.

Methods: We conducted a national cross-sectional survey in 2007 using the World Health Organization tool to evaluate injection safety practices. Using 2-stage cluster sampling, 80 government and 61 private health facilities were randomly selected and evaluated.

Results: There was no shortage of injection equipment nor evidence of attempts to sterilize disposable devices. Care providers immediately disposed of the used needle/syringe in sharps containers. Phlebotomy devices were taken from sealed packets in $96 \%$ of facilities. In private facilities, $66.3 \%$ of the care providers were fully immunized against hepatitis B. Wearing a new pair of gloves for phlebotomy was observed in only $46 \%$ of government and $38 \%$ of private health facilities. Many health facilities lacked alcohol-based handrub.

Conclusions: Many injection safety aspects were satisfactory. However there are still opportunities for improvement. Actions are required to make alcohol-based handrub and appropriate sharps containers available and to provide hepatitis $B$ vaccine and training to health care workers in all facilities.

Keywords: Blood-borne viruses, injection safety, assessments tool, Oman, Eastern Mediterranean Region

Citation: Al Awaidy S; Zayed B; Ramadan M; Hsairi M. Assessment of safe injection practices in health facilities in Oman. East Mediterr Health J. 2018;24(4):351-359. https://doi.org/10.26719/2018.24.4.351

Received: 20/07/16; accepted: 05/03/17

Copyright (C) World Health Organization (WHO) 2018. Some rights reserved. This work is available under the CC BY-NC-SA 3.o IGO license (https:// creativecommons.org/licenses/by-nc-sa/3.o/igo).

\section{Introduction}

Injections are the most common health care procedure; it is estimated that 16 billion are administered each year (1), with several billion given every year in low- and middle-income countries $(1,2,3)$. The World Health Organization (WHO) has estimated that 2 million needle-stick injuries occur annually to health care workers worldwide; these can result in transmission of hepatitis B and C and HIV infection $(4,5)$. Therefore, addressing the safety of injection-related practices and risk factors and making prophylactic care available are the best precautions against accidental transmission.

Injections are safe when they pose no threat to the recipient, the provider or the community (6). This requires the use of sterile needles, clean preparation surfaces, and immediate and proper disposal of used devices as well as an effective and safe method of final disposal to avoid infectious and noninfectious adverse events. The adequacy and appropriateness of injection equipment, the use of sharps containers, the level of staffing, and the incidence of recapping, the awareness of risk, and the effectiveness and availability of training also affect risk of transmission of infections $(6,7)$.
Substantial efforts have been made by the international community, under the leadership of the Safe Injection Global Network (SIGN), to reduce the risk of unsafe injections worldwide (8). Significant progress was made in reducing the number of unsafe injections in developing countries from 2000 to 2010 (from 1.35 to 0.16 per person per year). However, the number remained high in the countries of the WHO Eastern Mediterranean Region, with 0.57 unsafe injections per person per year. In sub-Saharan Africa and Latin America, the average figure for 2010 was only 0.04-0.05 unsafe injections per person per year (9).

In 2001, the Ministry of Health in Oman conducted a national survey of injection practices in 78 government health facilities across the country. The findings of the study suggested that overall standards were good; however, in some areas, there was a need to improve the situation. Examples of areas identified by the 2001 study and requiring further strengthening, including increasing awareness regarding the Ministry of Health injection safety policy, streamlining request procedures for injection supplies and safe final disposal of sharps (10). 
We assessed the injection practices in both governmental and private health care facilities for phlebotomies, lancet procedures and intravenous (IV) injections and infusions. The main objectives of this study were to determine whether facilities meet the requirements for practices, equipment, supplies and waste disposal. Secondly, we aimed to identify unsafe practices that posed a risk to patients, providers and the community.

\section{Methods}

\section{Study design}

In this cross-sectional study, facilities were randomly selected through a 2-stage cluster sampling design (11). We used the 2007 WHO revised tool for the assessment of injection safety (12). The study was implemented in 2007 over 2 phases: The first phase was the preparation and piloting, and the second was conducting the study, entry and analysis of data and reporting.

\section{Study sites and sampling}

At the time of the survey, Oman was administered through 8 regions and 2 governorates (currently Oman is divided into 11 governorates) and we used these for sampling purposes. The regions were divided into 61 wilayat (districts). We assessed injection safety in 2 representative samples, one in the public health sector and the second in the private health sector. In the public health sector, a representative sample was selected from the 52 governmental hospitals and the 152 health centres. Population data were obtained from the most recent estimate (13). Prior to sampling, wilayat which had less than 10 health facilities were regrouped with the immediately adjacent one to form larger units. This provided a sampling frame of 16 clusters, from which a sample of 8 clusters was selected (first-stage sampling) with probability proportionate to population size (14). All health facilities in the selected clusters were listed and a sample of 10 (1 regional hospital and 9 health facilities) was drawn using a simple random sampling technique using a table of random numbers (second-stage sampling).

In the private health sector, and due to the number of injections, only hospitals, medical complexes and dental clinics were retained. Sampling was done in the 8 geographical clusters randomly selected for the public health sector survey. In each of these geographical clusters, 1 hospital was randomly selected if there was at least 1 ; for the 2 other categories we considered that a medical complex with a dental clinic represented 1 unified health structure. If the medical complex did not have a dental clinic, the closest dental clinic to this medical complex was enrolled. Replacements was also chosen for the few health facilities which did not administer injection procedures.

\section{Data collection tool}

Data were collected using the questionnaire of the revised WHO Tool $\mathrm{C}$ for the assessment of unsafe practices (12); this used a combination of interviews and structured observations to estimate the risk of infection associated with unsafe practices for each type of procedure. The aims were to assess whether a facility meets the requirements for safety, to identify unsafe practices and to estimate the proportion of health care facilities in which practices are safely (or unsafely) performed. The assessment includes a checklist, and responses are mostly categorical options in order to both standardize the assessment and simplify data management and analysis. It was designed to target public and private facilities providing primary care, including first and second level hospitals.

\section{Piloting}

The study was piloted in 5 health facilities in Muscat, both public and private. Consequently, we modified the language of some questions in the survey questionnaire to make it clearer to both investigators and interviewees. These 5 facilities were not included in the survey.

\section{Data collection and analysis}

A research team of 32 fieldworkers were trained on data collection and interviewing. They were grouped into 9 teams; each was responsible for one of the 8 clusters $(2$ teams collected data from one of the cluster as facilities were situated far apart in that cluster). Data were collected using a combination of structured observation and interviews. Data collectors conducted the observations for the facility, worksites, supplies and practices according to a core set of checklist items. Observation included facility infrastructure and the following practices: injection, blood collection, IV injection and infusion, sterilization and waste disposal. Fieldworkers were instructed to observe 1-5 observations for each of the procedures related to the assessment. All of the observations had to be compatible with the standard/best practice to consider the procedure safe. Data collectors were instructed to spend at least 3 hours in the facility before concluding that a procedure was not observed. They would not ask for a procedure to be performed if it was not already a planned part of the patient's treatment. Data collectors interviewed the provider and his/her immediate supervisor. Monitoring and supervision were provided by the principal investigators and co-investigators; an item-by-item check ron consistency, plausibility and completeness of the data collection forms was done and appropriate corrections were made on-site.

Data entry and management were done using EpiData, version 3.1, and Stata, version 6.o. Data analysis was done separately for the public and private health sectors. We calculated the proportion of facilities having the desired response for each item and the confidence interval (CI) or the statistical range of the proportion of facilities having that characteristic. Due to differences in the number of injection procedures between clusters, adjustments were done by assigning weights in each cluster for both public and private health sectors taking into account the number of procedures. Binomial confidence intervals were computed using Stata. The cluster-sampling design was taken into account by 
computing the Kish design effect, the value by which the variance is underestimated compared to the variance obtained from simple random sampling (15), and by using the design effect to make the appropriate corrections to the $95 \% \mathrm{CI}$.

\section{Ethical considerations}

Informed consent was obtained from the health care workers in the selected facilities. Fieldworkers had been trained to tactfully intervene to prevent potential harm if they were about to witness injection practices that were of particular danger to the recipient.

This study was approved by the Research Ethics Committee of the Ministry of Health, Oman.

\section{Results}

\section{Assessment of risks to patients}

Of the 141 health facilities surveyed, 80 (57\%) were in in the public health sector and $61(43 \%)$ in the private sector (Table 1).

Details of the safety assessment observation for patients and providers are given in Table 2. There was

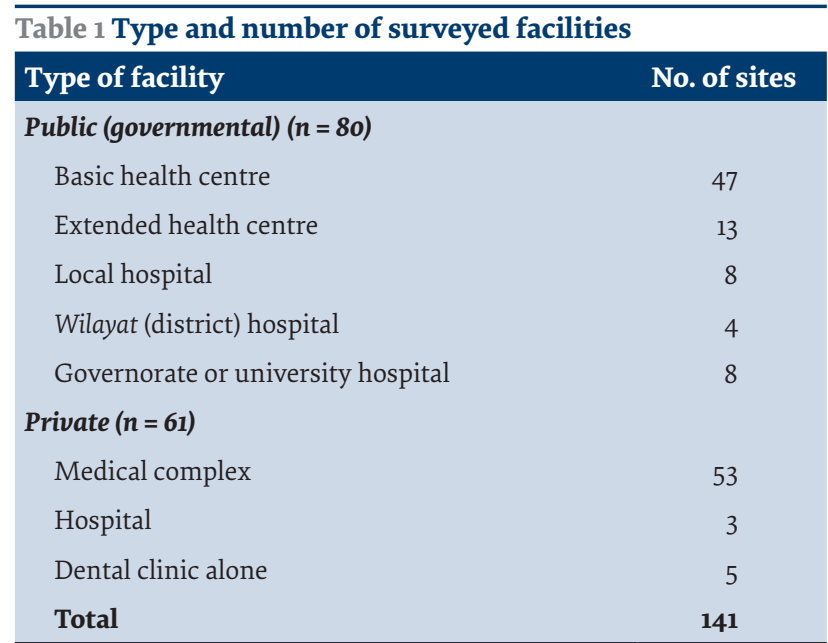

no evidence of attempts to sterilize disposable injection devices and all facilities were equipped with running water and cleansing soap. In most of the facilities we surveyed no needles were left in the diaphragm of multidose vials (95\%, (CI) 89-99\%). However, infectious (nonsharps) health care waste was observed outside of their

\begin{tabular}{|c|c|c|c|c|c|c|}
\hline \multirow[t]{2}{*}{ Indictor } & \multicolumn{3}{|c|}{ Public sector } & \multicolumn{3}{|c|}{ Private sector } \\
\hline & $n$ & $N$ & $\%(95 \% \mathrm{CI})$ & $n$ & $N$ & $\%(95 \% \mathrm{CI})$ \\
\hline \multicolumn{7}{|l|}{ Assessing risk to patients } \\
\hline $\begin{array}{l}\text { No loose disposable injection equipment outside of packaging } \\
\text { anywhere inside the facility }\end{array}$ & 71 & 80 & $88(82-96)$ & 45 & 61 & $73(58-88)$ \\
\hline $\begin{array}{l}\text { No loose disposable phlebotomy equipment outside of } \\
\text { packaging anywhere inside the facility }\end{array}$ & 72 & 77 & $94(88-99)$ & 42 & 46 & $90(81-100)$ \\
\hline $\begin{array}{l}\text { No loose disposable intravenous equipment outside of } \\
\text { packaging anywhere inside the facility }\end{array}$ & 78 & 80 & $98(94-100)$ & 49 & 53 & $93(83-100)$ \\
\hline $\begin{array}{l}\text { Evidence of attempted sterilization of disposable injection } \\
\text { equipment }\end{array}$ & 0 & 80 & 0 & 0 & 61 & 0 \\
\hline $\begin{array}{l}\text { No non-sharps infectious health care waste of any type outside } \\
\text { of containers specific for non-sharps infectious waste }\end{array}$ & 54 & 80 & $68(57-78)$ & 44 & 61 & $72(59-85)$ \\
\hline No multi-dose vials with needles left in the diaphragm & 75 & 80 & $94(88-99)$ & 58 & 61 & $94(87-100)$ \\
\hline Running water and soap for cleansing hands & 80 & 80 & 100 & 61 & 61 & 100 \\
\hline Alcohol-based hand rub for cleansing hands & 28 & 80 & $35(24-46)$ & 11 & 61 & $18(5-32)$ \\
\hline \multicolumn{7}{|l|}{ Assessing risk to providers } \\
\hline $\begin{array}{l}\text { No overflowing or pierced sharps containers of any type in any } \\
\text { area of the facility }\end{array}$ & 70 & 80 & $88(80-95)$ & 48 & 61 & $79(68-91)$ \\
\hline No used sharps in an open container in any area of the facility & 59 & 80 & $74(64-84)$ & 34 & 61 & $56(40-71)$ \\
\hline $\begin{array}{l}\geq 1 \text { puncture-resistant and leak-proof sharps container in all } \\
\text { areas where vaccinations are given }\end{array}$ & 73 & 79 & $92(86-98)$ & 14 & 40 & $36(22-50)$ \\
\hline $\begin{array}{l}\geq 1 \text { puncture-resistant and leak-proof sharps container in all } \\
\text { areas where therapeutic injections are given }\end{array}$ & 75 & 80 & $94(88-99)$ & 49 & 61 & $80(68-92)$ \\
\hline $\begin{array}{l}\geq 1 \text { puncture-resistant and leak-proof sharps container in all } \\
\text { areas where phlebotomies are performed }\end{array}$ & 78 & 78 & 100 & 42 & 46 & $90(82-99)$ \\
\hline $\begin{array}{l}\geq 1 \text { puncture-resistant and leak-proof sharps container in all } \\
\text { areas where intravenous procedures are performed }\end{array}$ & 77 & 79 & $98(94-100)$ & 37 & 52 & $72(57-86)$ \\
\hline$\geq 1$ puncture-resistant safety container in stock & 78 & 80 & $98(94-100)$ & 31 & 61 & $50(35-65)$ \\
\hline
\end{tabular}

$n=$ weighted proportion numerator, $N=$ proportion denominator, $C I=$ confidence interval 
specific containers in $32 \%$ of public and in $40 \%$ of private facilities. Alcohol-based handrub was available in $35 \%$ of governmental and $18 \%$ of private facilities (Table 2 ).

No sterilizable (reusable) needles or syringes were used in either public or private facilities for vaccinations or therapeutic and family planning injections. Syringes and needles were taken from a sterile packet in $96 \%, 98 \%$ and $100 \%$ of public facilities for vaccinations, therapeutic injections and family planning respectively and in $100 \%$, $98 \%$ and $100 \%$ of private facilities. For injections that require reconstitution, all syringes and needles were taken from a sealed packet in both public and private facilities. The diluents used for reconstitution were from the same manufacturer that made the vaccine in all the surveyed public and private facilities. On the other hand, it was reported that only in $32 \%$ of the public and $40 \%$ of the private facilities providers cleansed the access diaphragm of multi-dose vials with antiseptic before inserting a needle into the vial. Using a clean barrier to protect fingers when opening a glass ampoule was not common practice, and was observed in $54 \%$ of public and $77 \%$ of private health facilities (Table 3 ).

In $86 \%$ of public and $76 \%$ of private facilities; phlebotomies were prepared on a clean, dedicated table

Table 3 Assessment of safety of injection practices in the public and private health sectors, Oman, 2007

\begin{tabular}{|c|c|c|c|c|c|c|}
\hline \multirow[t]{2}{*}{ Indictor } & \multicolumn{3}{|c|}{ Public sector } & \multicolumn{3}{|c|}{ Private sector } \\
\hline & $n$ & $N$ & $\%(95 \% \mathrm{CI})$ & $n$ & $N$ & $\%(95 \% \mathrm{CI})$ \\
\hline \multicolumn{7}{|l|}{ Assessing risk to patients } \\
\hline \multicolumn{7}{|l|}{$\begin{array}{l}\text { Injections prepared on a clean, dedicated table or tray where } \\
\text { contamination of the equipment with blood, body fluids or } \\
\text { dirty swabs is unlikely }\end{array}$} \\
\hline Vaccinations & 56 & 63 & $89(81-96)$ & 14 & 15 & $94(80-100)$ \\
\hline Therapeutic & 57 & 62 & $92(85-99)$ & 35 & 44 & $79(63-95)$ \\
\hline Family planning & 19 & 21 & $89(76-100)$ & 6 & 8 & $81(46-100)$ \\
\hline Dental & 27 & 32 & $86(75-97)$ & 41 & 46 & $90(81-99)$ \\
\hline Total & 69 & 73 & $94(89-99)$ & 45 & 57 & $79(67-91)$ \\
\hline \multicolumn{7}{|l|}{$\begin{array}{l}\text { Syringes and needles for injections taken from a sterile packet } \\
\text { or fitted with caps }\end{array}$} \\
\hline Vaccinations & 59 & 62 & $96(91-100)$ & 12 & 12 & 100 \\
\hline Therapeutic & 60 & 61 & $98(95-100)$ & 42 & 43 & $98(95-100)$ \\
\hline Family planning & 17 & 17 & 100 & 6 & 6 & 100 \\
\hline Dental & 18 & 24 & $76(48-100)$ & 34 & 37 & $91(81-100)$ \\
\hline Total & 67 & 73 & $92(85-98)$ & 49 & 54 & $91(83-99)$ \\
\hline $\begin{array}{l}\text { For reconstitutions, syringe and needle taken from sealed } \\
\text { packet or fitted with caps }\end{array}$ & 48 & 48 & 100 & 16 & 16 & 100 \\
\hline $\begin{array}{l}\text { Diluents used for vaccine reconstitutions is from the same } \\
\text { manufacturer that made the vaccine }\end{array}$ & 47 & 47 & 100 & 11 & 11 & 100 \\
\hline $\begin{array}{l}\text { Providers cleansed access diaphragm of multi-dose vials } \\
\text { with antiseptic before inserting a needle into the vial }\end{array}$ & 10 & 31 & $32(15-50)$ & 5 & 13 & $40(1-78)$ \\
\hline $\begin{array}{l}\text { Provider used a clean barrier to protect fingers when } \\
\text { opening a glass ampoule }\end{array}$ & 27 & 50 & $54(40-68)$ & 27 & 35 & $77(50-100)$ \\
\hline $\begin{array}{l}\text { Temperature sensitive vaccines kept at } 2-8^{\circ} \mathrm{C} \text { during period } \\
\text { of use }\end{array}$ & 62 & 62 & 100 & 9 & 13 & $71(23-100)$ \\
\hline \multicolumn{7}{|l|}{ Assessing risk to providers } \\
\hline $\begin{array}{l}\text { Absence of recapping of needles after administering a } \\
\text { vaccination }\end{array}$ & 56 & 62 & $91(84-98)$ & 9 & 14 & $62(20-100)$ \\
\hline $\begin{array}{l}\text { Absence of } 2 \text {-handed recapping of needles after } \\
\text { administering a therapeutic injection }\end{array}$ & 57 & 61 & $94(87-99.9)$ & 23 & 42 & $54(35-72)$ \\
\hline $\begin{array}{l}\text { After vaccinations, the provider immediately disposed of the } \\
\text { used needle/syringe in an appropriate sharps container }\end{array}$ & 62 & 62 & 100 & 14 & 14 & 100 \\
\hline $\begin{array}{l}\text { After therapeutic injections, the provider immediately } \\
\text { disposed of used needle/syringe in an appropriate sharps } \\
\text { container }\end{array}$ & 57 & 61 & $94(87-100)$ & 17 & 23 & $73(50-100)$ \\
\hline $\begin{array}{l}\text { During IV procedures (including phlebotomies), providers } \\
\text { palpate the venepuncture site after skin preparation with an } \\
\text { antiseptic }\end{array}$ & 30 & 58 & $51(40-70)$ & 34 & 41 & $84(68-100)$ \\
\hline
\end{tabular}

$n=$ weighted proportion numerator, $N$ = proportion denominator, $C I=$ confidence interval; $I V=$ intravenous. 
or tray (Table 4). Cleaning skin at the puncture site with antiseptics before skin puncture was observed in $87 \%$ of the public and only $63 \%$ of the private facilities. In both public and private facilities, devices used for phlebotomies were taken from a sterile packet in $96 \%$ of the facilities.

In $88 \%$ of the public and $81 \%$ of the private facilities, preparation for lancet procedures was done on a clean, dedicated table or tray (Table 5). Lancets were taken from a sterile packet, in approximately $96 \%$ of the public and in $92 \%$ of the private facilities.

Intravenous injection/infusion devices were taken from a sterile packet in $93 \%$ of the public facilities but in only $73 \%$ of the private facilities (Table 6). On the other hand, palpation of the venepuncture site by providers (after skin preparation with an antiseptic) was reported in $51 \%$ of public and $63 \%$ of private health facilities. Cleansing the IV port with antiseptics before access was observed in $75 \%$ of public but only $39 \%$ of private health facilities. Appropriate access of the IV port (i.e. no injections were administered directly into IV bags, plastic bottles or IV tubing), was reported from 39\% of the private health facilities vs $61 \%$ of the public health sector (Table 6).

\section{Interview with provider}

The providers interviewed had not experienced nee- dle-stick injury in the previous 6 months in $80 \%$ of facilities in both the public and private sector (Table 7). Around $86 \%$ of interviewed providers in governmental and only $66 \%$ of private facilities have been fully immunized by hepatitis B vaccine. Only $58 \%$ of providers in public and $21 \%$ in private health facilities received training on injection safety in the previous 2 years.

\section{Assessment of rislc to care providers}

There was $\geq 1$ puncture-resistant, leak-proof sharps container in all rooms where phlebotomies were performed in the governmental facilities, but in less than $90 \%$ of the private facilities. Open containers for sharps disposal were still seen in both public (26\%) and private $(44 \%)$ health facilities (Table 2).

After vaccinations, all care providers immediately disposed of used needles/syringes in an appropriate sharps container (Table 3). On the other hand, after therapeutic injections comparative values are $94 \%$ of public and $73 \%$ of private facilities. Recapping of syringes in vaccination rooms was observed in $9 \%$ of public and $38 \%$ of private facilities. For therapeutic injections, recapping was observed in $6 \%$ of public and $36 \%$ of private facilities.

Wearing a new pair of gloves for a phlebotomy was observed in only $46 \%$ of public and $38 \%$ of private health facilities (Table 4). Two-handed recapping of any needles after performing phlebotomy was observed in $73 \%$ of

\begin{tabular}{|c|c|c|c|c|c|c|}
\hline \multirow[t]{2}{*}{ Indictor } & \multicolumn{3}{|c|}{ Public sector } & \multicolumn{3}{|c|}{ Private sector } \\
\hline & $\mathbf{n}$ & $\mathbf{N}$ & $\%(95 \% \mathrm{CI})$ & $\mathbf{n}$ & $\mathbf{N}$ & $\%(95 \% \mathrm{CI})$ \\
\hline \multicolumn{7}{|l|}{ Assessing risk to patients } \\
\hline $\begin{array}{l}\text { Phlebotomies prepared on a clean, dedicated table or tray where } \\
\text { contamination of the equipment with blood, body fluids or dirty } \\
\text { swabs is unlikely }\end{array}$ & 55 & 64 & $86(78-95)$ & 22 & 29 & $76(56-95)$ \\
\hline $\begin{array}{l}\text { Skin at the puncture site is prepared before a phlebotomy using CHG } \\
2 \% \text {, povidine-iodine or alcohol before skin puncture }\end{array}$ & 53 & 61 & $87(78-95)$ & 18 & 28 & $63(35-91)$ \\
\hline $\begin{array}{l}\text { For each phlebotomy, the device used was taken from a sterile packet } \\
\text { or fitted with caps }\end{array}$ & 59 & 62 & $96(90-100)$ & 28 & 29 & $96(87-100)$ \\
\hline \multicolumn{7}{|l|}{ Assessing risk to providers } \\
\hline $\begin{array}{l}\text { Providers appropriately secured the patient and the intended } \\
\text { puncture site so that the patient could not move during the } \\
\text { procedure }\end{array}$ & 56 & 61 & $92(86-99)$ & 25 & 29 & $85(69-100)$ \\
\hline Phlebotomists wear a new pair of gloves for a phlebotomy & 29 & 62 & $46(33-59)$ & 11 & 28 & $38(15-62)$ \\
\hline $\begin{array}{l}\text { Uncapped needles were not removed from phlebotomy holder/ } \\
\text { adapters using only hands }\end{array}$ & 46 & 61 & $75(64-86)$ & 6 & 27 & $22(0.0-53)$ \\
\hline $\begin{array}{l}\text { No 2-handed recapping of any needles after performing } \\
\text { phlebotomies }\end{array}$ & 17 & 62 & $27(15-39)$ & 17 & 28 & $62(34-89)$ \\
\hline $\begin{array}{l}\text { Blood was not transferred from a syringe/needle directly into a } \\
\text { vacuum tube using a 2-handed technique }\end{array}$ & 12 & 40 & $29(14-44)$ & 11 & 18 & 60 (21-99) \\
\hline $\begin{array}{l}\text { Provider disposed of sharps immediately after the procedure in an } \\
\text { appropriate sharps container }\end{array}$ & 55 & 61 & $90(82-98)$ & 26 & 28 & $92(80-100)$ \\
\hline $\begin{array}{l}\text { Immediately after the procedure, the provider disposed of non- } \\
\text { sharps infectious waste in a container specific for non-sharps } \\
\text { infectious waste }\end{array}$ & 56 & 62 & $91(83-98)$ & 20 & 28 & $58(30-85)$ \\
\hline
\end{tabular}

$n=$ weighted proportion numerator, $N$ = proportion denominator, $C I=$ confidence interval; $C H G$ = chlorhexidine gluconate 


\begin{tabular}{|c|c|c|c|c|c|c|}
\hline \multirow[t]{2}{*}{ Indictor } & \multicolumn{3}{|c|}{ Public sector } & \multicolumn{3}{|c|}{ Private sector } \\
\hline & $n$ & $N$ & $\%(95 \% \mathrm{CI})$ & $n$ & $N$ & $\%(95 \% \mathrm{CI})$ \\
\hline \multicolumn{7}{|l|}{ Assessing risk to patients } \\
\hline $\begin{array}{l}\text { Lancet procedures are prepared on a clean, dedicated table or } \\
\text { tray where contamination of the equipment with blood, body } \\
\text { fluids or dirty swabs is unlikely }\end{array}$ & 58 & 66 & $88(80-96)$ & 32 & 39 & $81(64-97)$ \\
\hline $\begin{array}{l}\text { For each lancet procedure, a lancet is taken from a sterile } \\
\text { packet, or fitted with a cap }\end{array}$ & 64 & 67 & $96(92-100)$ & 38 & 41 & $92(83-100)$ \\
\hline \multicolumn{7}{|l|}{ Assessing risk to providers } \\
\hline $\begin{array}{l}\text { Providers appropriately secured the patient and the intended } \\
\text { puncture site so that the patient could not move during the } \\
\text { procedure }\end{array}$ & 60 & 67 & $89(81-98)$ & 37 & 38 & $97(92-100)$ \\
\hline $\begin{array}{l}\text { Immediately after the procedure, the provider disposed of } \\
\text { sharps in an appropriate sharps container }\end{array}$ & 62 & 67 & $93(86-99)$ & 32 & 40 & $80(63-97)$ \\
\hline $\begin{array}{l}\text { Immediately after the procedure, the provider disposed of } \\
\text { non-sharps infectious waste in a container specific for non- } \\
\text { sharps infectious waste }\end{array}$ & 58 & 63 & $92(86-99)$ & 23 & 35 & $66(45-86)$ \\
\hline
\end{tabular}

$n=$ weighted proportion numerator, $N=$ proportion denominator, $C I=$ confidence interval .

public but only $38 \%$ of private health facilities. Blood was transferred from a syringe/needle directly into a vacuum tube using a 2-handed technique in $71 \%$ of public but only $40 \%$ of private health facilities. Immediately after procedures, the provider disposed of non-sharps infectious waste in the specific container in $91 \%$ of public but only $58 \%$ of private health facilities (Table 4 ).

Providers appropriately secured the patient and the intended puncture site so that the patient could not move during the procedure in $89 \%$ and $97 \%$ of public and private facilities respectively. Proportion of facilities surveyed in which the provider disposed sharps in appropriate sharps container, immediately after the procedure, is 93\% and $80 \%$ for public and private facilities respectively. Appropriate disposal of non-sharps infectious waste was observed in $92 \%$ of public and $66 \%$ of private facilities (Table 5).

Providers appropriately secured the patient and the intended puncture site in $91 \%$ of both public and private facilities (Table 6). Wearing a new pair of gloves for each IV injection was practised in $44 \%$ of public and. $65 \%$ of private health facilities, while wearing new gloves for each time an IV infusion was started or IV catheter was changed was reported in $53 \%$ of public but only $24 \%$ of private facilities. Nevertheless, 2-hand recapping of needles after IV injections/infusions was observed in $40 \%$ of private and in only $11 \%$ of public facilities.

\section{Risk to the community}

Sharps containers awaiting final disposal were completely closed in only $53 \%$ of private facilities and in $82 \%$ of facilities in public sector. Sharps containers awaiting final disposal were stored in a locked area, in only in 50\% of facilities in private and $72 \%$ in the public sector.

\section{Discussion}

The main findings of the study indicate that shortage of injection equipment was rare and no evidence of attempts to sterilize the single-use injection equipment was observed. We also found that all syringes and needles were taken from a sealed packet in all health facilities. Additionally, the used needle/syringe were immediately disposed of in the appropriate sharps containers.

On the other hand, the situation in regard to IV injections and infusions was less satisfactory compared to other injections, phlebotomy and lancet procedures for both sectors, especially for private facilities. Although all facilities were equipped with running water and cleansing soap, alcohol-based handrub was available in only a few facilities. Ministry of Health intervention would be required to make alcohol-based rub available for public health care facilities and to promote it as standard in private facilities as well. It is important to note that in more than $95 \%$ of private health facilities, neither 'injection safety', nor "health care waste management" policy or guidelines were available.

This study was the second formal assessment at the national level to evaluate the safety of injections, phlebotomies, lancet procedures and IV procedures. The 2001 study concluded that the overall standards were good; however, there were some clusters of concern where safe practices need to be strengthened. This survey was conducted using the old version of Tool C, which concerns only immunization and therapeutic injection in primary health care $(15,16)$. The particular difference between this study and the previous assessment conducted in 2001 is the inclusion of both government and private health facilities. The 2001 study assessed facilitates providing primary care services only (10). 


\begin{tabular}{|c|c|c|c|c|c|c|}
\hline \multirow[t]{2}{*}{ Indictor } & \multicolumn{3}{|c|}{ Public sector } & \multicolumn{3}{|c|}{ Private sector } \\
\hline & $n$ & $N$ & $\%(95 \% \mathrm{CI})$ & $n$ & $N$ & $\%(95 \% \mathrm{CI})$ \\
\hline \multicolumn{7}{|l|}{ Assessing risk to patients } \\
\hline \multicolumn{7}{|l|}{$\begin{array}{l}\text { Intravenous procedures prepared on a clean, dedicated table or tray where } \\
\text { contamination of equipment with blood, body fluids or dirty swabs is unlikely: }\end{array}$} \\
\hline IV injections & 27 & 11 & $86(72-100)$ & 17 & 18 & $61(40-82)$ \\
\hline IV infusions & 31 & 36 & $85(73-97)$ & 12 & 19 & $61(29-93)$ \\
\hline $\begin{array}{l}\text { Skin at puncture site is prepared before an IV procedure using } \mathrm{CHG} 2 \% \text {, povidone- } \\
\text { iodine or alcohol, and allowed to dry before puncture }\end{array}$ & 30 & 41 & $74(58-90)$ & 17 & 23 & $73(46-100)$ \\
\hline $\begin{array}{l}\text { Provider palpated the venepuncture site after skin preparation with an antiseptic } \\
\text { during IV procedures (including phlebotomies) }\end{array}$ & 30 & 58 & $51(32-70)$ & 17 & 27 & $63(36-90)$ \\
\hline $\begin{array}{l}\text { At start of each IV infusion or IV catheter change the device was taken from a sterile } \\
\text { packet }\end{array}$ & 39 & 42 & $93(86-100)$ & 17 & 23 & $73(47-99)$ \\
\hline $\begin{array}{l}\text { For each procedure performed on an IV system using a needle/syringe, the IV system } \\
\text { was accessed from an IV port }\end{array}$ & 17 & 23 & $75(50-100)$ & 7 & 18 & $39(10-68)$ \\
\hline $\begin{array}{l}\text { Injection ports are cleansed with CHG } 2 \% \text {, povidone-iodine or alcohol before accessing } \\
\text { the IV system }\end{array}$ & 15 & 26 & $60(40-80)$ & 9 & 16 & $50(10-90)$ \\
\hline \multicolumn{7}{|l|}{ Assessing risk to providers } \\
\hline $\begin{array}{l}\text { Provider appropriately secured the patient and the intended puncture site so that the } \\
\text { patient could not move during the procedure }\end{array}$ & 64 & 70 & $91(85-97)$ & 39 & 43 & $91(83-100)$ \\
\hline Provider wore a new pair of gloves for each intravenous injection & 14 & 31 & $44(25-63)$ & 12 & 18 & $65(38-92)$ \\
\hline $\begin{array}{l}\text { Provider wore a new pair of gloves each time an intravenous infusion was started or an } \\
\text { intravenous catheter was changed }\end{array}$ & 17 & 33 & $53(34-72)$ & 4 & 18 & $24(1-47)$ \\
\hline $\begin{array}{l}\text { No 2-handed recapping of any needles after performing intravenous injections } \\
\text { occurred }\end{array}$ & 36 & 41 & $89(78-100)$ & 14 & 23 & $60(28-92)$ \\
\hline $\begin{array}{l}\text { Provider disposed of sharps in an appropriate sharps container immediately after } \\
\text { procedure }\end{array}$ & 35 & 41 & $85(74-96)$ & 15 & 21 & $72(45-99)$ \\
\hline $\begin{array}{l}\text { Provider disposed of non-sharps infectious waste immediately after the procedure in a } \\
\text { container specific for non-sharps infectious waste }\end{array}$ & 34 & 40 & $86(73-99)$ & 13 & 24 & $55(24-86)$ \\
\hline
\end{tabular}

$n=$ weighted proportion numerator; $N=$ proportion denominator; $C I=$ confidence interval; $C H G=$ chlorhexidine gluconate.

In the 2001 study in Oman, recapped needles were observed in sharp-containers in $28 \%$ of the facilities (10). In Nigeria there was a high unsafe injection practice among Primary Health Care workers in Ilorin metropolis, with $86.7 \%$ of health facilities using needle recapping after administration of injection (17), while in Swaziland the situation was worse; changing needles in the same syringe and recapping of needles after use were observed in 31\% of health facilities (18).

In our study, the providers interviewed had not experienced needle-stick injury in the previous 6 months in $80 \%$ of facilities in both the public and private sectors; this compares with the findings of the 2001 study where $17.9 \%$ of the providers had reported needle-stick injuries

\begin{tabular}{|c|c|c|c|c|c|c|}
\hline \multirow[t]{2}{*}{ Item } & \multicolumn{3}{|c|}{ Public sector } & \multicolumn{3}{|c|}{ Private sector } \\
\hline & $n$ & $N$ & $\%(95 \% \mathrm{CI})$ & $n$ & $N$ & $\%(95 \%$ CI $)$ \\
\hline $\begin{array}{l}\text { No stock-outs of puncture-resistant sharps containers during the } \\
\text { previous } 6 \text { months }\end{array}$ & 62 & 80 & $78(68-87)$ & 51 & 61 & $84(73-93)$ \\
\hline $\begin{array}{l}\text { Provider did not experience any needle-stick injury in the previous } \\
6 \text { month }\end{array}$ & 64 & 80 & $80(71-89)$ & 49 & 61 & $80(69-92)$ \\
\hline $\begin{array}{l}\text { Provider had injection safety training available to them within the } \\
\text { previous } 2 \text { years in a lecture or workshop }\end{array}$ & 46 & 79 & $58(47-69)$ & 12 & 59 & $21(10-32)$ \\
\hline Provider had received $\geq 3$ doses of hepatitis B vaccine & 69 & 80 & $86(79-94)$ & 40 & 61 & $66(53-80)$ \\
\hline
\end{tabular}

$n=$ weighted proportion numerator; $N$ = proportion denominator; $C I=$ confidence interval 
in the previous year (10).

In Nigeria there was a highly unsafe injection practice among primary health care workers in Ilorin metropolis, with $86.7 \%$ of health facilities using needle recapping after administration of injections (17); in Swaziland the situation was worse: changing needles in the same syringe and recapping of needles after use were observed in $31 \%$ of health facilities (18). In comparison, in our study, recapping of syringes after vaccination was observed in $9 \%$ of public and 38\% of private facilities and for therapeutic injections, recapping was observed in $6 \%$ of public and $36 \%$ of private facilities.

The main limitations in this study were related to its nationwide scope, thus there was no capacity to identify disparities between regions and health districts. Additionally, some collected information, e.g. needle-stick injuries and hepatitis B immunization, were based on self-declaration by the providers.

\section{Conclusions}

Our findings indicate broad compliance with injection practices as defined by WHO. Many injection-safety aspects were satisfactory: supplies were available, single-use syringes were used and practices were reasonable. However, action is required to make alcohol-based handrubs and appropriate sharps containers available and provide hepatitis B vaccine and training for health care workers in both governmental and private facilities.

\section{Acknowledgements}

We would like to thank Dr Ali Bin Moosa, the late Dr Ali Jaffer Mohammed, the late Dr Ahmed Al Ghassani, Dr Mohammed Al Hosani, Dr Jihane Tawilah, Dr Irtaza Chaudhry, Dr Idris Al Obaidani and the national study team (Mr Hussameddine Nawar, Mr Salem Al-Mahrooqi, Ms Maraim Al-Shaibi, Ms Deborah Samuel, Ms Salima Al-Harthy, Ms Salha Jaffer, Mr Khalil Al-Hassani and Ms Amira Al-Hadi) for their guidance and support.

Funding: The study was funded by World Health Organization and Ministry of Health of Oman.

Competing interests: None declared.

\section{Évaluation des pratiques d'injection sans risque dans les établissements de santé à Oman \\ RÉSUMÉ}

Contexte: Les pratiques d'injection dangereuses soumettent les patients et les prestataires de soins au risque de connaître des événements indésirables infectieux ou non infectieux. Une enquête du ministère de la Santé en 2001 sur les pratiques d'injection à Oman a indiqué que, si elles étaient généralement d'un bon niveau, il existait toutefois un besoin d'amélioration dans certains domaines.

Objectif : Notre objectif était d'évaluer les pratiques de sécurité des injections afin de déterminer si les établissements satisfont aux exigences en matière de pratiques, de matériel, de fournitures et d'élimination des déchets et d'identifier les pratiques à risque.

Méthodes : Nous avons réalisé une étude transversale nationale en 2007 à l'aide de l'outil de l'Organisation mondiale de la Santé pour évaluer la sécurité des pratiques d'injection. Le recours à l'échantillonnage par grappe à deux niveaux a permis de sélectionner au hasard et d'évaluer 80 établissements de santé publics et 61 établissements privés.

Résultats : Il n'y avait aucune pénurie de matériel d'injection et aucune preuve de tentatives de stériliser des appareils jetables. Les prestataires de soins jetaient immédiatement les aiguilles/seringues utilisées dans les boîtes prévues pour l'élimination des objets coupants et tranchants. Les dispositifs de phlébotomie étaient prélevés d'emballages scellés dans $96 \%$ des établissements. Dans les établissements privés, 66,3\% des prestataires de soins étaient complètement vaccinés contre l'hépatite B. Le port d'une nouvelle paire de gants pour pratiquer une phlébotomie n'a été observé que dans $46 \%$ des établissements de santé publics et dans 38\% des établissements privés. De nombreux établissements de santé n'avaient pas suffisamment de solutions hydroalcooliques.

Conclusions : De nombreux aspects relatifs à la sécurité des injections étaient satisfaisants. Il est toutefois possible d'améliorer encore davantage ce domaine. Des mesures sont requises afin de mettre à disposition des solutions hydroalcooliques et des boîtes adéquates pour l'élimination des objets coupants et tranchants et de fournir le vaccin contre l'hépatite B ainsi qu'une formation aux agents de soins de santé dans tous les établissements.

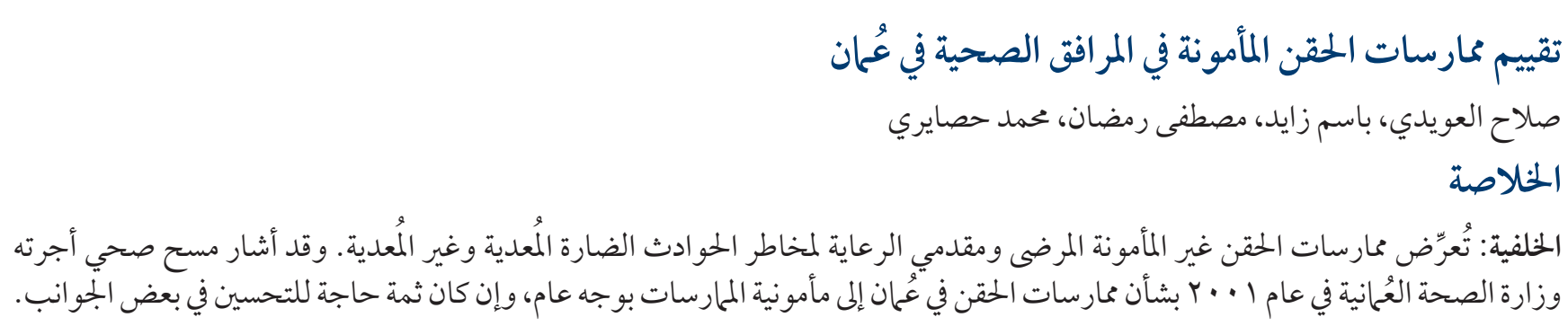


الهدف: هدفنا إلى تقييم ممارسات الحقن المأمونة لتحديد مدى استيفاء المرافق للشروط المتعلقة بالمارسات و المعدات والمستلزمات والتخلص من النفايات، وتحديد الممارسات غير فير المأمونة.

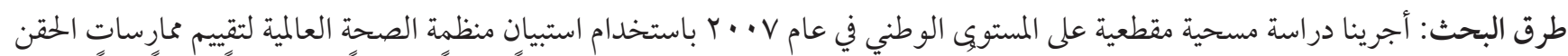

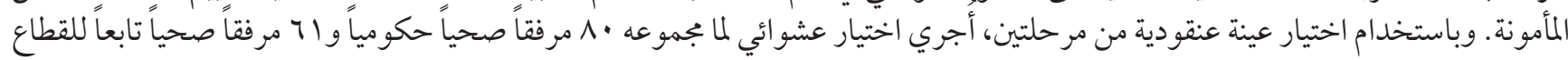
الخاص وتقييمها.

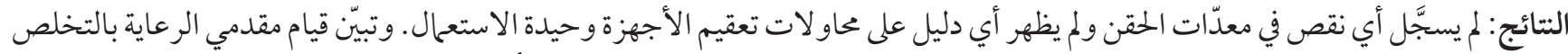

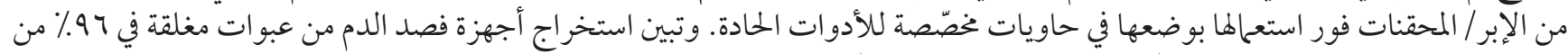

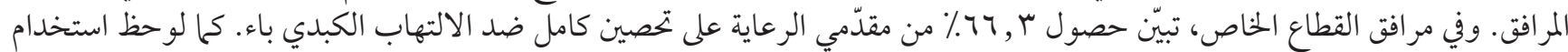

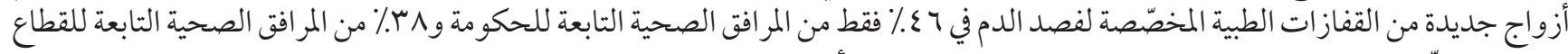

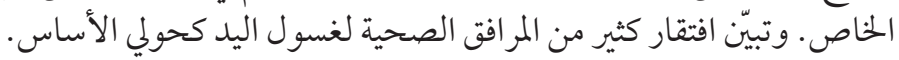

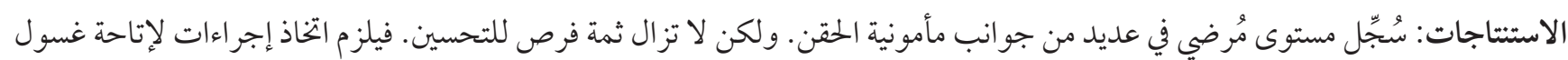

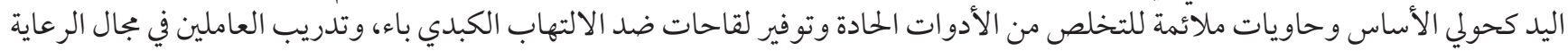
الصحية في جميع المرافق.

\section{References}

1. Hauri AM, Armstrong GL, Hutin YJ. The global burden of disease attributable to contaminated injections given in health care settings. Int J STD AIDS. 2004,15(1):7-16. PMID:14769164

2. Kane A, Lloyd J, Zaffran M, Simonsen L, Kane M. Transmission of hepatitis B, hepatitis C and human immunodeficiency viruses through unsafe injections in the developing world: model-based regional estimates. Bull World Health Organ. 1999;77:801-7. PMID:10593027

3. Van Staa A, Hardon A: Injection practices in the developing world: results and recommendations from field studies in Uganda and Indonesia. Geneva: World Health Organization; 1996 (http://apps.who.int/medicinedocs/pdf/s2232e/s2232e.pdf, accessed 30 October 2017).

4. Sagoe-Moses C, Pearson JD, Perry J, Jagger J. Risks to health care workers in developing countries. N Engl J Med. 2001;345(7):53841. doi:10.1056/NEJM200108163450711

5. Wilburn S, Eijkemans G. Preventing needle-stick injuries among healthcare workers: a WHO-ICN collaboration. Int J Occup Environ Health. 2004;10(4)451-6. PMID:15702761

6. Hutin Y, Hauri A, Chiarello L, Catlin M, Stilwell B, Ghebrehiwet T, et al. Best infection control practices for intradermal, subcutaneous, and intramuscular needle injections. Bull World Health Organ. 2003;81(7):491-500. PMID:12973641

7. Safe Injection Global Network, World Health Organization, International Council of Nurses. Best infection control practices for skin-piercing, intradermal, subcutaneous and intramuscular needle injections. Geneva: World Health Organization; 2001 (WHO/ BCT/DCT 01.02).

8. Summary of country injection safety success stories. SIGN Alliance; 2013 (http://www.who.int/infection-prevention/publications/country_success/en/, accessed 16 December 2017).

9. Pépin J, Abou Chakra CN, Pe'pin E, Nault V. Evolution of the global use of unsafe medical injections, 2000-2010. PLoS One. 2013;8(12):e80948. PMID:24911341

10. Al Awaidy S, Bawikar S, Duclos P. Safe injection practices in a primary health care setting in Oman. East Mediterr Health J. 2006;12(Suppl. 2):S207-16. PMID:17361692

11. Bennett S, Woods T, Liyanage WM, Smith DL. A simplified general method for cluster-sample surveys of health in developing countries. World Health Stat Q. 1991;44:98-106. PMID:1949887

12. Revised injection safety assessment tool (Tool C-revised): tool for the assessment of injection safety and the safety of phlebotomy, lancet procedures, IV injections and infusions. Geneva: World Health Organization; 2008 (WHO/EHT/08.08.10).

13. Annual health report, Oman: Introduction. Muscat: Ministry of Health; 2007 (https://www.moh.gov.om/en_US/web/statistics/-/2007-, accessed 16 December 2017).

14. Lemeshow S, Hosmer DW, Klar D, Lwanga StK. Adequacy of sample size in health studies. Chichester: John Wiley \& Sons; 1990:59-60.

15. Kish L. Survey sampling. New York: John Wiley \& Sons, Inc; 1965.

16. Tool for the assessment of injection safety. Geneva: World Health Organization; 2001 (WHO/V\&B/01.30).

17. Bolarinwa OA, Salaudeen AG, Aderibigbe SA, Musa OI, Akande TM. Injection safety practice among primary health care workers in Ilorin, Kwara state of Nigeria. Health Sci J. 2012;6:1495-508.

18. Daly AD, Nxumalo MP, Biellik RJ. An assessment of safe injection practices in health facilities in Swaziland. S Afr Med J.

2004;94:194-7. PMID:15098279. 